\title{
Synthesis and Fluorescence Properties of Europium-Lanthanum-Calcium Orthophosphates and Condensed Phosphates
}

\author{
Hiroaki Onoda, Takehiro Funamoto \\ Department of Informatics and Environmental Sciences, Kyoto Prefectural University, Kyoto, Japan \\ Email: onoda@kpu.ac.jp
}

Received July 31, 2012; revised September 1, 2012; accepted September 7, 2012

\begin{abstract}
Mixtures of lanthanum oxide, europium oxide, calcium carbonate, and phosphoric acid were heated with various ratios of $\mathrm{P} /(\mathrm{Eu}+\mathrm{La}+\mathrm{Ca})$ and $\mathrm{La} / \mathrm{Ca}$. Europium ratio was settled at $\mathrm{Eu} /(\mathrm{Eu}+\mathrm{La}+\mathrm{Ca})=0.03$. The obtained phosphates were estimated using X-ray diffraction (XRD) patterns, Fourier transform infrared spectroscopy (FT-IR) spectra, and scanning electron micrograph (SEM) images. The fluorescence spectra and resistance against hydrofluoric acid were estimated as functional properties of these phosphate materials. The mixture of lanthanum and calcium phosphates were formed from XRD patterns and IR spectra. Samples prepared in $\mathrm{P} /(\mathrm{Eu}+\mathrm{La}+\mathrm{Ca})=2$ and 3 had large particles in SEM images. The condensed phosphates showed a strong peak at $615 \mathrm{~nm}$ and high resistance against hydrofluoric acid.
\end{abstract}

Keywords: Condensed Phosphate; Europium; Fluorescence; Resistance against Hydrofluoric Acid

\section{Introduction}

Phosphates are transformed to other forms of phosphates by hydrolysis and dehydration reactions at elevated temperatures $[1,2]$. Polyphosphate and ultraphosphate are included in a group of condensed phosphates. Polyphosphate has a chain structure in which the $\mathrm{PO}_{4}$ unit shares two oxygen atoms and ultraphosphate has a network structure. Formation of these condensed phosphates was affected by the ratio of phosphorus/cation, heating temperature, time, atmosphere, and so on [3-5]. Therefore, it was difficult to obtain a high yield of the condensed phosphates. Consequently, orthophosphate has been investigated for various uses, but condensed phosphates have been little studied. Orthophosphate materials have been used for ceramic materials, catalysts, fluorescent materials, dielectric substances, metal surface treatment, detergent, food additives, fuel cells, pigments, etc. [6,7]. The condensed phosphates have different properties from those of orthophosphates and can therefore be used as novel functional materials $[8,9]$.

Rare-earth phosphates have a high melting point and large specific surface area in phosphate materials $[10,11]$. Rare-earth orthophosphates, which are the main component of rare-earth ores, are stable phosphate groups in acidic and basic solutions. Their resistance in acidic and basic solutions was developed into other phosphate materials [12]. Moreover, rare earth elements are important in fluorescence properties. Especially, the addition of europium indicated strong fluorescence in materials of various kinds [13].

Metals, oxides, and silicates are useful materials, but they are vulnerable to the effects of hydrofluoric acid, which is a reagent used in many industrial applications. However, its wastes are not easily disposed of [14]. Furthermore, throughout Africa, China, the Middle East, and southern Asia (India and Sri Lanka), groundwater contains a certain amount of hydrofluoric acid. Therefore, for materials used with such polluted water from plants and at the developing area, resistance against hydrofluoric acid is important [15]. Because phosphate materials have a certain degree of resistance against hydrofluoric acid, these materials can be used with hydrofluoric acid. Nevertheless, the extent of that resistance remains unclear.

In previous work [9], europium-substituted lanthanum phosphates were synthesized and estimated from the optical properties and the resistance against hydrofluoric acid. The substitution from rare earth cations to common metal cations is important, because rare earth cations are limited in the world. The motivation of this work is to repress the use of lanthanum cation. For this study, the europium-substituted lanthanum-calcium condensed phosphates were synthesized from lanthanum oxide, calcium carbonate, europium oxides, and phosphoric acid. The respective chemical compositions and particle shapes of the obtained products were evaluated. Fur- 
thermore, these phosphate materials were studied for their fluorescence properties and resistance in hydrofluoric acid.

\section{Experimental}

Europium oxide $\left(\mathrm{Eu}_{2} \mathrm{O}_{3}\right)$ was mixed with lanthanum oxide $\left(\mathrm{La}_{2} \mathrm{O}_{3}\right)$ and calcium carbonate $\left(\mathrm{CaCO}_{3}\right)$ in the ratio of $\mathrm{Eu} /(\mathrm{Eu}+\mathrm{La}+\mathrm{Ca})=0.03$ and $\mathrm{La} / \mathrm{Ca}=10 / 0,8 / 2,5 / 5$, $2 / 8$, and $0 / 10$. These mixtures were added to phosphoric acid $\left(\mathrm{H}_{3} \mathrm{PO}_{4}\right)$ at mole ratios of $\mathrm{P} /(\mathrm{La}+\mathrm{Ca}+\mathrm{Eu})=1,2$, and 3 , and then heated at $700^{\circ} \mathrm{C}$ for $20 \mathrm{hr}$ under air conditions.

The respective chemical compositions of these thermal products were analyzed using X-ray diffraction (XRD) and Fourier transform infrared spectroscopy (FT-IR). X-ray diffraction patterns were recorded on a Rigaku Denki RINT2000 X-Ray diffractometer using monochromated $\mathrm{CuK} \alpha$ radiation. The IR spectra were recorded (FT/IR-4200; JASCO Corp.) using a $\mathrm{KBr}$ disk method. The particle shapes of phosphate powder were observed from scanning electron micrographs (SEM, JGM-5510LV; JEOL).

The excitation and emission properties were measured using a luminescence spectrometer (LS55; Perkin-Elmer). The emission and excitation wavelengths were 620 and $254 \mathrm{~nm}$, respectively. The resistance of materials against hydrofluoric acid was estimated using the following method. The $0.2 \mathrm{~g}$ of thermal products was allowed to stand in $100 \mathrm{ml}$ of $5 \mathrm{wt} \%$ of hydrofluoric acid for 1 day. Then, a solid was removed by filtration. The residual ratio was calculated with the dried solid.

\section{Results and Discussion}

\subsection{Chemical Compositions and Particle Shapes of Phosphates}

Samples prepared in $\mathrm{P} /(\mathrm{La}+\mathrm{Ca}+\mathrm{Eu})=1$ and $\mathrm{La} / \mathrm{Ca}=$ $10 / 0$ indicated the peaks of lanthanum orthophosphate, $\mathrm{LaPO}_{4}$. By the substitution from lanthanum to calcium cation, the peaks of calcium phosphate, $\mathrm{Ca}_{3}\left(\mathrm{PO}_{4}\right)_{2}$, appeared in XRD patterns. In $\mathrm{P} /(\mathrm{La}+\mathrm{Ca}+\mathrm{Eu})=2$, XRD patterns were changed from lanthanum orthophosphate, $\mathrm{LaPO}_{4}$, and polyphosphate, $\mathrm{La}\left(\mathrm{PO}_{3}\right)_{3}$ to calcium polyphosphate, $\mathrm{Ca}\left(\mathrm{PO}_{3}\right)_{2}$. Figure 1 shows XRD patterns of samples prepared in $\mathrm{P} /(\mathrm{La}+\mathrm{Ca}+\mathrm{Eu})=3$. The peaks of lanthanum polyphosphate, $\mathrm{La}\left(\mathrm{PO}_{3}\right)_{3}$, became small by the substitution with calcium cation in the preparation conditions. Sample prepared in $\mathrm{La} / \mathrm{Ca}=0 / 10$ was near amorphous state because of the abundant phosphate. In the condition at $\mathrm{P} / \mathrm{Ca}=3 / 1$, samples had no stable calcium phosphate from XRD patterns.

Figure 2 portrays IR spectra of samples prepared in $\mathrm{P} /(\mathrm{La}+\mathrm{Ca}+\mathrm{Eu})=1$. Sample prepared in $\mathrm{La} / \mathrm{Ca}=10 / 0$

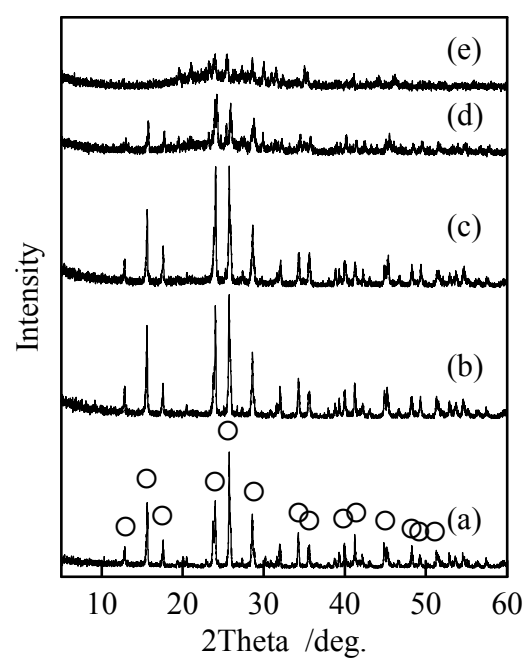

Figure 1. XRD patterns of samples prepared in $\mathrm{P} /(\mathrm{La}+\mathrm{Ca}$ $+\mathrm{Eu})=3$ (Eu; $3 \mathrm{~mol} \%$ ), (a) $\mathrm{La} / \mathrm{Ca}=10 / 0 ;$ (b) $\mathrm{La} / \mathrm{Ca}=8 / 2$; (c) $\mathrm{La} / \mathrm{Ca}=5 / 5$; (d) $\mathrm{La} / \mathrm{Ca}=2 / 8$; and (e) $\mathrm{La} / \mathrm{Ca}=0 / 10$; : $\mathrm{La}\left(\mathrm{PO}_{3}\right)_{3}$.

indicated the adsorption due to orthophosphate, on the other hand, sample in $\mathrm{La} / \mathrm{Ca}=0 / 10$ had the adsorption of condensed phosphates. The most important peak at 770 $\mathrm{cm}^{-1}$ was from P-O-P bonding in condensed phosphates [16]. Sample prepared in $\mathrm{La} / \mathrm{Ca}=0 / 10$ was the mixture of calcium orthophosphate, $\mathrm{Ca}_{3}\left(\mathrm{PO}_{4}\right)_{2}$, and calcium pyrophosphate, $\mathrm{Ca}_{2} \mathrm{P}_{2} \mathrm{O}_{7}$, from XRD patterns and IR spectra. The small absorption peak at $1630 \mathrm{~cm}^{-1}$ in the spectrum of all samples was attributable to the adsorbed water after thermal synthesis. Sample prepared in $\mathrm{La} / \mathrm{Ca}=0 / 10$ had more obvious peak at $1630 \mathrm{~cm}^{-1}$, because condensed phosphate was easy to contain the adsorbed water. Samples prepared in $\mathrm{P} /(\mathrm{La}+\mathrm{Ca}+\mathrm{Eu})=2$ and 3 had smaller change than that in $\mathrm{P} /(\mathrm{La}+\mathrm{Ca}+\mathrm{Eu})=1$, because the formation of condensed phosphate had much influence on IR spectra. The difference of condensation degree among condensed phosphates had little change in IR spectra.

From SEM images, the $\mathrm{P} /(\mathrm{La}+\mathrm{Ca}+\mathrm{Eu})$ ratio had more influence on particle shape and size than the $\mathrm{La} / \mathrm{Ca}$ ratio. Figure 3 depicts SEM images of samples prepared with various $\mathrm{P} /(\mathrm{La}+\mathrm{Ca}+\mathrm{Eu})$ and $\mathrm{La} / \mathrm{Ca}=5 / 5$. Samples prepared in $\mathrm{P} /(\mathrm{La}+\mathrm{Ca}+\mathrm{Eu})=1$ had small particles. On the other hand, samples prepared in $\mathrm{P} /(\mathrm{La}+\mathrm{Ca}+\mathrm{Eu})=2$ and 3 had large particles. All samples had no specified shape in this work.

\subsection{Functional Properties of Phosphate Materials}

Figure 4 portrays the excitation and emission spectra of samples prepared in $\mathrm{P} /(\mathrm{La}+\mathrm{Ca}+\mathrm{Eu})=2$ (emission: 620 $\mathrm{nm}$, excitation: $254 \mathrm{~nm}$ ). Samples prepared in $\mathrm{La} / \mathrm{Ca}=$ $10 / 0$ had the strong peaks at $250-270 \mathrm{~nm}$ in excitation 


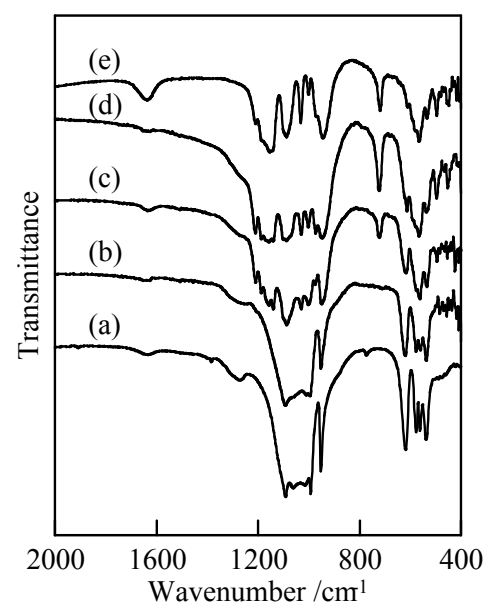

Figure 2. IR spectra of samples prepared in $\mathrm{P} /(\mathrm{La}+\mathrm{Ca}+$ $\mathrm{Eu})=3$ (Eu; $3 \mathrm{~mol} / \mathrm{l})$. (a) $\mathrm{La} / \mathrm{Ca}=10 / 0$; (b) $\mathrm{La} / \mathrm{Ca}=8 / 2$; (c) $\mathrm{La} / \mathrm{Ca}=5 / 5 ;$ (d) $\mathrm{La} / \mathrm{Ca}=2 / 8 ;$ (e) $\mathrm{La} / \mathrm{Ca}=0 / 10$.
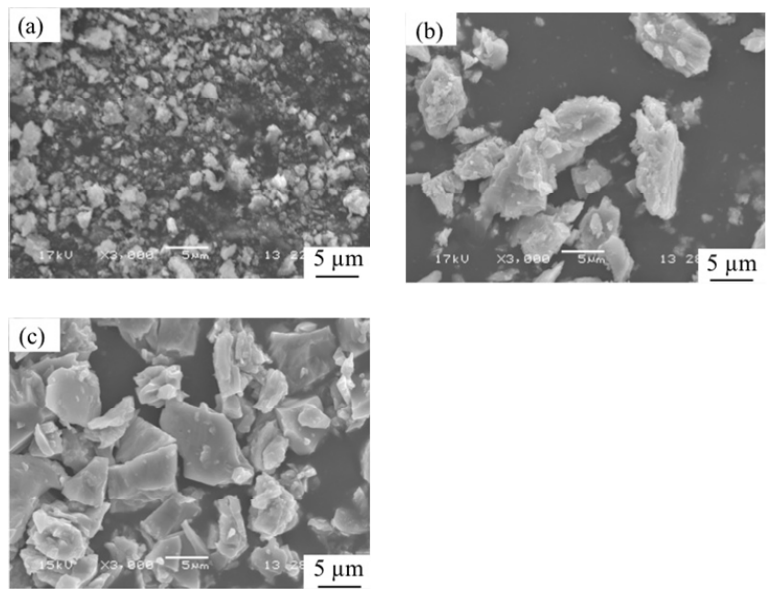

Figure 3. SEM images of samples prepared in $\mathrm{La} / \mathrm{Ca}=\mathbf{5} / \mathbf{5}$. (a) $\mathrm{P} /(\mathrm{La}+\mathrm{Ca}+\mathrm{Eu})=1$; (b) $\mathrm{P} /(\mathrm{La}+\mathrm{Ca}+\mathrm{Eu})=2$; and (c) $\mathbf{P} /(\mathbf{L a}+\mathbf{C a}+\mathbf{E u})=\mathbf{3}$.

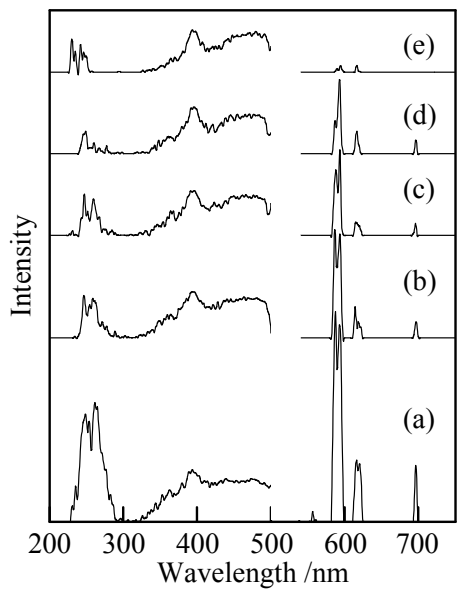

Figure 4. Excitation $(620 \mathrm{~nm})$ and emission $(254 \mathrm{~nm})$ spectra of samples prepared in $\mathrm{P} /(\mathrm{La}+\mathrm{Ca}+\mathrm{Eu})=2(\mathrm{Eu} ; 3$ mol\%). (a) $\mathrm{La} / \mathrm{Ca}=10 / 0$; (b) $\mathrm{La} / \mathrm{Ca}=8 / 2$; (c) $\mathrm{La} / \mathrm{Ca}=5 / 5$; (d) $\mathrm{La} / \mathrm{Ca}=2 / 8$; and (e) $\mathrm{La} / \mathrm{Ca}=0 / 10$. spectra. The emission peaks at 556, 590, 615, and 690 $\mathrm{nm}$ corresponded respectively to the transition from ${ }^{5} \mathrm{D}_{0}$ to ${ }^{7} \mathrm{~F}_{0},{ }^{7} \mathrm{~F}_{1},{ }^{7} \mathrm{~F}_{2}$, and ${ }^{7} \mathrm{~F}_{4}$. Some peaks were divided in two because of the symmetry of phosphate structure. The strong peaks at $615 \mathrm{~nm}$ were observed at sample prepared in $\mathrm{La} / \mathrm{Ca}=10 / 0$. The peak intensity was weak for samples prepared in $\mathrm{La} / \mathrm{Ca}=0 / 10$ (Figure 4(e)). The existence of lanthanum cation in phosphate structure was important for the emission peaks. Samples prepared in $\mathrm{P} /(\mathrm{La}+\mathrm{Ca}+\mathrm{Eu})=1$ and 3 had little emission peaks by the small substitution with calcium cation $(\mathrm{La} / \mathrm{Ca}=8 / 2$, not shown). The substitution with calcium cation produced amorphous phase in XRD patterns of samples at $\mathrm{P} /(\mathrm{La}+$ $\mathrm{Ca}+\mathrm{Eu})=1$ and 3. In this work, amorphous materials had little fluorescence peaks. On the other hand, the crystalline calcium polyphosphate, $\mathrm{Ca}\left(\mathrm{PO}_{3}\right)_{2}$, formed in the condition of $\mathrm{P} / \mathrm{Ca}=2$. Because of this crystalline calcium polyphosphate, the emission intensity became small gradually.

Table 1 presents the residual ratios of samples from 5 $w t \%$ of hydrofluoric acid. A high residual ratio reflects high resistance against hydrofluoric acid. All samples showed residual ratios higher than $60 \%$. The condensed phosphates showed high resistance against hydrofluoric acid. The residual ratio became small by the substitution with calcium cation. In the same conditions, silicon dioxide was dissolved completely to hydrofluoric acid. The phosphate materials showed much higher resistance against hydrofluoric acid.

\section{Conclusion}

Europium-substituted lanthanum-calcium phosphates were synthesized from lanthanum oxide, calcium carbonate, europium oxide, and phosphoric acid. Lanthanum and calcium phosphates were formed from XRD patterns and IR spectra. From SEM images, samples prepared in $\mathrm{P} /(\mathrm{La}+\mathrm{Ca}+\mathrm{Eu})=2$ and 3 had large particles. By the substitution with calcium, the fluorescence peak of samples prepared in $\mathrm{P} /(\mathrm{La}+\mathrm{Ca}+\mathrm{Eu})=2$ became weak

Table 1. Residual ratio of samples from hydrofluoric acid \%.

\begin{tabular}{cccc}
\hline $\mathrm{La} / \mathrm{Ca}$ & \multicolumn{3}{c}{$\mathrm{P} /(\mathrm{La}+\mathrm{Ca}+\mathrm{Eu})$} \\
& 1 & 2 & 3 \\
\hline $10 / 0$ & 74.6 & 83.7 & 79.3 \\
$8 / 2$ & 70.4 & 86.2 & 86.7 \\
$5 / 5$ & 71.5 & 85.7 & 82.0 \\
$2 / 8$ & 63.6 & 86.7 & 80.5 \\
$0 / 10$ & 60.6 & 81.8 & 88.6 \\
\hline
\end{tabular}


gradually. The formation of calcium phosphate had influence on the emission spectra of phosphates. These phosphate materials had a high residual ratio from hydrofluoric acid.

\section{REFERENCES}

[1] M. T. Averbuch-Pouchat and A. Durif, "Topics in Phosphate Chemistry," World Scientific Publishing Co. Pte. Ltd., Singapore City, 1996.

[2] I. Hammas, K. Horchani-Naifer and M. Ferid, "Conduction Properties of Condensed Lanthanum Phosphates: $\mathrm{La}\left(\mathrm{PO}_{3}\right)_{3}$ and $\mathrm{LaP}_{5} \mathrm{O}_{14}$," Journal of Rare Earths, Vol. 28, No. 3, 2010, pp. 321-328. doi:10.1016/S1002-0721(09)60106-X

[3] S. Raynaud, E. Champion, D. Bernache-Assollant and P. Thomas, "Calcium Phosphate Apatites with Variable $\mathrm{Ca} / \mathrm{P}$ Atomic Ratio I. Synthesis, Characterization and Thermal Stability of Powders," Biomaterials, Vol. 23, No. 4, 2002, pp. 1065-1072. doi:10.1016/S0142-9612(01)00218-6

[4] B. Boonchom, C. Danvirutai and S. Maensiri, "Soft Solution Synthesis, Non-Isothermal Decomposition Kinetics and Characterization of Manganese Dihydrogen Phosphate Dihydrate $\mathrm{Mn}\left(\mathrm{H}_{2} \mathrm{PO}_{4}\right)_{2} \cdot 2 \mathrm{H}_{2} \mathrm{O}$ and Its Thermal Transformation Products," Materials Chemistry and Physics, Vol. 109, No. 2-3, 2008, pp. 404-410. doi:10.1016/i.matchemphys.2007.12.018

[5] S. V. Rathan and G. Govindaraj, "Thermal and Electrical Relaxation Studies in $\mathrm{Li}_{(4+x)} \mathrm{Ti}_{x} \mathrm{Nb}_{1-x} \mathrm{P}_{3} \mathrm{O}_{12}(0.0 \leq x \leq 1.0)$ Phosphate Glasses," Solid State Sciences, Vol. 12, No. 5, 2010, pp. 730-735.

doi:10.1016/j.solidstatesciences.2010.02.030

[6] P. Shuetz and F. Caruso, "Electrostatically Assembled Fluorescent Thin Films of Rare-Earth-Doped Lanthanum Phosphate Nanoparticles," Chemistry of Materials, Vol. 14, No. 11, 2002, pp. 4509-4516. doi: $10.1021 / \mathrm{cm} 0212257$

[7] F. Meiser, C. Cortez and F. Caruso, "Biofunctionalization of Fluorescent Rare-Earth-Doped Lanthanum Phosphate Colloidal Nanoparticles," Angewandte Chemie, Vol. 43, No. 44, 2004, pp. 5954-5957. doi:10.1002/anie. 200460856

[8] H. Onoda, H. Nariai, A. Moriwaki, H. Maki and I. Mo- tooka, "Formation and Catalytic Characterization of Various Rare Earth Phosphates," Journal of Materials Chemistry, Vol. 12, No. 6, 2002, pp. 1754-1760. doi: $10.1039 / \mathrm{b} 110121 \mathrm{~h}$

[9] H. Onoda and T. Funamoto, "Synthesis and Fluorescence Properties of Europium-Substituted Lanthanum Orthophosphate and Condensed Phosphates," Advances in Materials Physics and Chemistry, Vol. 2, No. 1, 2012, pp. 50-54. doi:10.4236/ampc.2012.21008

[10] K. Rajesh, P. Shajesh, O. Seidei, P. Mukundan and K. G. K. Warrier, "A Facile Sol-Gel Strategy for the Synthesis of Rod-Shaped Nanocrystalline High-Surface-Area Lanthanum Phosphate Powders and Nanocoatings," Advanced Functional Materials, Vol. 17, No. 10, 2007, pp. 1682-1690. doi:10.1002/adfm.200600794

[11] H. Onoda, K. Taniguchi and I. Tanaka, "Additional Effects of Urea on Preparation and Acidic Properties of Lanthanum Orthophosphate," Microporous and Mesoporous Materials, Vol. 109, No. 1-3, 2008, pp. 193-198. doi:10.1016/j.micromeso.2007.04.043

[12] H. Onoda, H. Matsui and I. Tanaka, "Improvement of Acid and Base Resistance of Nickel Phosphate Pigment by the Addition of Lanthanum Cation," Materials Science and Engineering B, Vol. 141, No. 1-2, 2007, pp. 28-33. doi:10.1016/j.mseb.2007.05.009

[13] M. Bettinelli, F. Piccinelli, A. Speghini, J. Ueda and S. Tanabe, "Excited State Dynamics and Energy Transfer Rates in $\mathrm{Sr}_{3} \mathrm{~Tb}_{0.90} \mathrm{Eu}_{0.10}\left(\mathrm{PO}_{4}\right)_{3}$," Journal of Luminescence, Vol. 132, No. 1, 2012, pp. 27-29. doi:10.1016/j.jlumin.2011.07.018

[14] A. Tor, "Removal of Fluoride from Water Using AnionExchange Membrane under Donnan Dialysis Condition," Journal of Hazardrous Materials, Vol. 141, No. 3, 2007, pp. 814-818. doi:10.1016/j.jhazmat.2006.07.043

[15] C. M. Lew, Y. Liu, B. Day, G. M. Kloster, H. Tiznado, M. Sun, F. Zaera, J. Wang and Y. Yan, "Hydrofluoric-AcidResistant and Hydrophobic Pure-Silica-Zeolite MEL Low-Dielectric-Constant Films," Langmuir, Vol. 25, No. 9, 2009, pp. 5039-5044. doi:10.1021/1a803956w

[16] D. E. C. Corbridge and E. J. Lowe, "The Infra-Red Spectra of Inorganic Phosphorus Compounds. Part II. Some Salts of Phosphorus Oxy-Acids," Journal of the Chemical Society, Vol. 493, 1954, pp. 4555-4564. doi:10.1039/jr9540004555 